\title{
PERAN KAREL FREDERICK HOLLE DALAM PERKEMBANGAN PERTANIAN DAN PENDIDIKAN DI GARUT
}

\author{
Diky Muhamad Marzuki \\ Universitas Islam Negeri Sunan Gunung Djati Bandung \\ Email: dikymuhamadmarzuki20@gmail.com
}

\begin{abstract}
Abstarck
This paper discusses a very important figure in the development of language and literature in the city of Garut. Karel Frederick Holle was a Dutchman who came to the Indies at the age of 14 years. He began life in the Dutch East Indies as a housing administration employee in Cianjur. Followed by becoming a Dutch government employee in Batavia and ended up being an honorary advisor for land affairs in the administration department as well as a tea and coffee plantation owner in Cikajang Garut. This paper discusses K. F. Holle in outline. The author is aware of the lack of sources used due to the rare sources about $K . F$. Holle, therefore it needs further research in order to discuss all aspects in depth.
\end{abstract}

Kata Kunci: Dutch Policy, Indonesian farming, K. F. Holle 


\section{Pendahuluan}

Pada akhir abad ke-16, perang kemerdekaan Belanda melawan Spanyol memberikan pengaruh yang signifikan bagi Belanda, oleh karenanya bangsa Belanda berusaha keluar dari tekanan tersebut. Dahulu, bangsa Belanda bertindak sebagai perantara dalam menjual rempah-rempah secara eceran dari Portugis ke Eropa bagian utara. Menyatunya Spanyol dengan Portugis pada tahun 1580 mengacaukan jalur mereka untuk mendapatkan rempah-rempah dari Portugis, hal ini mendorong mereka untuk mencari sendiri sumber rempah-rempah, Nusantara adalah kawasan yang menjadi salah satu tujuan mereka. ${ }^{1}$

Dalam ekspedisi untuk menemukan Nusantara, Belanda melakukan dua kali pelayaran. Pelayaran pertama dipimpin oleh Cornelis de Houtman dan Peter de Keyser, mereka berhasil menemukan Nusantara. Mereka pertama kali menginjakkan kakinya di Banten pada 27 Juni 1596 dengan empat buah kapal, 249 awak kapal dan 64 meriam di kapal mereka. Pelayaran ke dua dipimpin oleh Jacob Cornelius van Neck yang juga datang ke Nusantara, tepatnya di Banten pada 25 November $1598 .{ }^{2}$

Seiring berjalannya waktu, kekuasaan Belanda yang diwakili oleh VOC (Verenegde Oostindische Compagnie) di Nusantara semakin menguat dan meluas, hingga VOC memiliki hasrat untuk menguasai Nusantara. Untuk menwujudkan hasratnya, VOC menggunakan berbagai cara yang diantaranya dengan menggunakan strategi kongsi dagang, memonopoli perekonomian Indonesia, Devide et Impera atau praktik adu domba, dan menaklukan kerajaan-kerajaan lokal.

Setelah Belanda dapat menguasai Indonesia, mereka menugaskan orang-orang Belanda untuk menjadi residen di berbagai wilayah di Indonesia, sehingga banyak sekali tokoh politik, tentara, pejabat ataupun pedagang berkebangsaan Belanda yang tinggal di Indonesia. Salah satu tokoh tersebut adalah Karel Frederick Holle. Ia adalah seorang yang sangat berjasa dalam perkembangan bahasa, sastra, dan pertanian di Kota Garut. Akan tetapi tidak banyak masyarakat yang mengenalnya, alasan inilah yang membuat penulis untuk membahas mengenai Peran Karel Frederick Holle dalam Pertanian dan Bahasa Sunda di Garut.

\footnotetext{
${ }^{1}$ M. Ricklefs, Sejarah Indonesia Modern 1200-2008 (Jakarta: PT. Ilmu Semesta, 2008).

${ }^{2}$ Anonim, "Karel Frederick Holle," n.d., https://id.wikipedia.org.
} 


\section{Metode}

Secara etimologis, kata sejarah berasal dari bahasa Arab, yaitu syajarah, yang artinya pohon, akar, keturunan, dan asal-usul. Dinamakan demikian karena fokus awal dari pembahasan sejarah adalah penulusuran terhadap geneologi yang umumnya digambarkan seperti pohon. ${ }^{3}$

Dalam metodologi sejarah, seorang sejarawan dituntut untuk menguasai metode yang digunakan agar mengetahui peristiwa di masa lampau. Untuk dilakukanlah penelitian berupa prosedur penyelidikan dengan menggunakan teknik pengumpulan data sejarah. Penelitian sejarah merupakan penelitian yang tergolong "metode sejarah", yaitu metode penelitian yang khusus digunakan dalam penelitian sejarah melalui tahapan tertentu.

Dalam tulisan ini, penulis menggunakan metode penelitian kepustakaan atau library research, dimana penulis terlebih dahulu mengumpulan data-data atau sumber yang berasal dari buku, artikel, jurnal, dan karya tulis ilmiah lainnya yang berkaitan dengan pembahasan yang sedang penulis bahas.

\section{Hasil dan Pembahasan}

\section{A. Kehidupan Karel Frederick Holle di Indonesia}

Pada tahun 1843 tepatnya pada bulan September, seorang Belanda bernama Karel Frederick Holle beserta keluarganya meninggalkan Belanda untuk pergi ke Indonesia yang pada saat itu terkenal dengan nama Hindia. Tujuannya adalah untuk mencoba peruntungan di negeri koloni, karena usaha keluarganya sebagai penyuling gula di Koblenz pada tahun 1836 berakhir dengan sia-sia. Tujuan ini juga yang menjadi alasan dasar mereka menerima tawaran Willem van der Hucht untuk pergi dan menetap di Hindia Belanda. ${ }^{4}$

Holle bersama kedua orang tuanya, yaitu Pieter Holle, seorang pengolah gula, dan Alexandrine Albertine van der Hucht, beserta pamannya yang bernama Willem van der Hucht datang ke Indonesia pada 18 Mei 1844 ketika usianya menginjak empat belas tahun. Setelah sampai di Hindia Belanda, orang tua K. F. Holle bekerja di Buitenzorg tepatnya di perkebunan

\footnotetext{
${ }^{3}$ Sulasman, Metodologi Penelitian Sejarah (Bandung: Pustaka Setia, 2014).

${ }^{4}$ Biografisch Woordenboek van Nederland 5 (Den Haag, 2002).
} 
Bolang sebagai administrator perkebunan kopi, sedangkan van der Hucht mendapat pekerjaan di sebuah perusahaan teh. ${ }^{5}$ Pekerjaan yang dilakoni oleh orang tuanya belum bisa membuat kehidupan keluarga Holle menjadi bahagia. Tahun-tahun pertama kehidupan K. F. Holle di Hindia Belanda sangat jauh dari kebahagiaan, cobaan pun datang silih berganti. ${ }^{6}$

Keadaan ini menyebabkan ibunya kebingungan dalam mengurusi kehidupan keluarganya di Hindia Belanda. Alasan inilah yang membuat Alexandrine Albertine menitipkan Holle kepada Gubernur Jendral Hindia Belanda di Bogor (Buitenzorg). Setelah beberapa tahun mendapatkan pendidikan di kantor Gubenur Jenderal Hindia Belanda di Bogor, Holle ditunjuk sebagai pegawai di kantor perumahan di Cianjur. ${ }^{7}$ Meskipun tidak genap satu tahun Holle tinggal di Cianjur, tetapi rasa cinta terhadap budaya Sunda telah tumbuh dalah hatinya, Ini terlihat ketika dia sering kali berbicara menggunakan bahasa Sunda dengan fasih. Hal tersebut bisa dibuktikan dengan pujian yang sering dilontarkan oleh teman dan rekannya dengan kalimat "Hij sprak het Soendanees als een Soendanees" artinya Dia berbicara bahasa Sunda seperti orang Sunda. ${ }^{8}$

\section{B. Kehidupan Karel Frederick Holle di Garut}

Kepindahannya dari Cianjur pada tahun 1847 membuat ia langsung diangkat menjadi juru tulis di Direktorat Kultures (pertanian) di Batavia. Setelah sepuluh tahun bekerja di pemerintah di Batavia, pada tahun 1856 dia berhenti dari pekerjaanya di Batavia karena ingin hidup mandiri dan bebas. Kemudian ia menjadi seorang administrator perusahaan teh di Cikajang, Garut. Sumber lain menyatakan Holle berhenti bekerja di Batavia dan pindah ke Garut bukanlah atas dasar kemauan dirinya, tapi karena ia ditunjuk oleh pemerintah sebagai pemilik dari perkebunan teh Waspada di Garut. ${ }^{9}$

Selama diam di Garut inilah K. F. Holle mulai melangkah lebih jauh dalam menekuni bahasa dan sastra Sunda, pertanian, dan karya seni kain batik khas Garut. Diceritakan juga bahwa dia menjalin persahabatan dengan seorang penghulu Limbangan bernama Raden Haji Moehammad Moesa,

\footnotetext{
${ }^{5}$ Biografisch Woordenboek van Nederland 5.

${ }^{6}$ Biografisch Woordenboek van Nederland 5.

${ }^{7}$ P A. L. H. Obreen \& L. Van Dam, K. F. Holle. De Telegraaf, 1896. 'Lihat juga D. Effendie, Raden Ajoe Lasminingrat (Garut: CV. Studio Proklamasi, 2011).

${ }^{8}$ S. K. Affandhi, Album Garoet Tempoe Doeloe (Garut, n.d.).

${ }^{9}$ Biografisch Woordenboek van Nederland 5.
} 
karena memiliki kesukaan yang sama terhadap budaya Sunda terutama bahasa dan satsra Sunda. Mereka pun menjalin persahabatan yang sangat kuat hingga akhir hayat. Bahkan mereka seringkali disebut sebagai dwitunggal yang sedang mewujudkan cita-citanya. ${ }^{10}$

Kecintaannya terhadap bahasa dan sastra Sunda ditunjukkan oleh Holle dengan berusaha memperjuangkan supaya bahasa Sunda kembali dipakai dalam bentuk tulisan. Pada akhirnya setelah ia berunding dengan R. M. Moesa ia berhasil menerapkan aksara cacarakan Hanacaraka yang berasal dari aksara Jawa sebagai aksara Sunda pada saat itu. ${ }^{11}$

Holle pun suka menerjemahkan buku-buku berbahasa Belanda ke dalam bahasa Sunda, mendokumentasikan folklore atau certa rakyat Sunda dan menerbitkannya dalam sebuah majalah bernama Mitra Noe Tani yang pertama kali terbit pada tahun 1866. Holle juga sering mengajarkan para pegawai di kebun tehnya untuk membuat batik dan memberikan bahan bacaan kepada anak-anak yang tinggal di sekitar perkebunan miliknya. ${ }^{12}$

Selain mengembangkan budaya Sunda khusunya bahasa dan sastra Sunda di Garut, Holle juga membantu Garut dalam mengembangkan dan memajukan sektor pertanian, salah satu usaha yang dilakukannya adalah dengan membawa benih-benih tanaman baru seperti kacang merah, kedelai, bawang, dan lain-lain. Benih-benih tanaman yang dibawa Holle ke Garut khususnya kacang merah adalah jenis tanaman yang baru dikenal oleh masyarakat pribumi, sehingga pada waktu itu kacang tersebut disebut dengan Kacang Holle. ${ }^{13}$

Sikap dan sifat baik yang diberikan Holle kepada masyarakat pribumi membuatnya disukai oleh banyak masyarakat pribumi, sehingga dirinya tidak dianggap lagi sebagai orang Belanda dan orang pribumi suka memanggilnya dengan sebutan Tuan Hola atau Tuan Holeu. Pada saat itu juga sering terdengar nyanyian-nyanyian dari siswa-siswi di sekolah yang lirik nyanyiannya berisikan pujian-pujian terhadap Holle. ${ }^{14}$

Prestasi gemilang yang dicapainya ketika bekerja di Cianjur dan Batavia serta banyaknya pribumi yang menyukai dirinya, membuat

\footnotetext{
${ }^{10}$ D Suhardiman, Budaya Garut Dan Pernak Perniknya (Garut: Komunitas Srimanganti, 2007).

${ }^{11}$ Effendie, Raden Ajoe Lasminingrat.

${ }^{12}$ Suhardiman, Budaya Garut Dan Pernak Perniknya.

${ }^{13}$ Affandhi, Album Garoet Tempoe Doeloe.

${ }^{14}$ Suhardiman, Budaya Garut Dan Pernak Perniknya.
} 
pemerintah Belanda yang saat itu dipimpin oleh Jenderal P. Meijer menawarkan jabatan sebagai Kepala Keresidenan di Garut, akan tetapi tawaran ini ditolak oleh Holle karena dirinya menganggap akan sulit untuk mewujudkan cita-citanya jika dia menduduki jabatan tersebut. Meskipun begitu, pemerintah Belanda tetap mengangkat dirinya menjadi penasihat kehormatan untuk urusan darat di departemen administrasi dalam negeri. ${ }^{15}$

Selama menduduki jabatan inilah Holle berhasil mendirikan sekolah Eropa (Bizondre Europeesche School) di Garut, Sekolah Pendidikan Guru (Kweekschool voor Onder Wijzers op Indlansche Schoolen) di Mardikaweg, Bandung atau yang sekarang terletak di Jl. Merdeka, Bandung. K. F. Holle juga berhasil mendorong Raden Ayu Lasminingrat, putri R. M. Moesa untuk mendirikan Sakola Kautamaan Istri yang diperuntukkan bagi masyarakat pribumi. ${ }^{16}$

Diluar ranah pendidikan, Holle juga memiliki lebih dari dua ratus publikasi atas nama dirinya. Ratusan tulisannya tersebut banyak menjelaskan mengenai budidaya ikan tawar dan budidaya padi. Tulisan mengenai prasasti Sunda Kuno dan peribahasa Sunda juga ada. Selain itu, ia memberikan nasihat-nasihat yang sangat banyak tentang peningkatan pertanian, khususnya pada budidaya padi. Nasihat Holle dalam budidaya padi ini jarang terdengar atau tidak didengar oleh kalangan orang desa di Jawa. Meskipun pemerintah memprioritaskan metode Holle, mereka tetap mempertahankan metode kerja tradisional mereka sendiri. ${ }^{17}$

Setelah 31 tahun tinggal di Garut, tepatnya pada tahun 1888, Holle meninggalkan Garut dan pindah ke Bogor untuk menyembuhkan penyakit yang dideritanya. Namun delapan tahun kemudian, tepatnya pada tahun 1896 Holle akhirnya meninggal dunia di Bogor dan dimakamkan di Tanah Abang, Jakarta. ${ }^{18}$

Jasa-jasa Holle tersebut membuat pemerintah Belanda membuatkan sebuah monumen di alun-alun Garut yang didalamnya tersematkan ukiran foto K. F. Holle, namanya juga disematkan dalam sebuah jalan dengan nama Hollestraat yang sekarang berubah menjadi Jl. Mandalagiri di Garut. Sayangnya monumen Holle hancur setelah kedatangan tentara Jepang ke

\footnotetext{
${ }^{15}$ Affandhi, Album Garoet Tempoe Doeloe.

${ }^{16}$ Suhardiman, Budaya Garut Dan Pernak Perniknya.

${ }^{17}$ Biografisch Woordenboek van Nederland 5.

${ }^{18}$ Affandhi, Album Garoet Tempoe Doeloe.
} 
Garut yang akan menghancurkan segala hal yang berbau Belanda di Garut. ${ }^{19}$

\section{Simpulan}

Karel Frederick Holle adalah seorang Belanda yang hijrah ke Hindia Belanda untuk memperbaiki nasib kehidupannya yang sulit ketika berada di Belanda. Kedatangannya ke Hindia Belanda membuahkan hasil yang cukup besar baginya. Selama tinggal di Hindia Belanda, ia berhasil menjadi penasihat kehormatan untuk urusan darat di departemen administrasi dalam negeri. Selain itu, dia juga berhasil membuat sebuah kemajuan dalam bidang pendidikan dan pertanian di tanah Priangan, tepatnya Garut. Dalam bidang literasi, Holle membuat sebuah majalah yang terkenal pada masanya, yaitu Mitra noe Tani. Majalah ini berisikan mengenai macam-macam cara bertani. Holle juga memiliki lebih dari dua ratus tulisan yang dipublikasikan dalam majalah, kebanyakan tulisannya membahas mengenai pertanian dan budidaya ikan.

Jasanya yang banyak ini membuat dirinya mendapat penghargaan dari pemerintah pada saat itu, tugu K. F Holle yang dibangun di alun-alun Garut adalah buktinya. Namanya pun dipakai sebagai nama jalan di Garut, yaitu Hollestraat, sekarang Jl. Mandalagiri. Holle meninggal di Bogor pada tahun 1856 dan dimakamkan di Tanah Abang, Jakarta.

K. F. Holle menjadi seorang Belanda yang mencintai budaya Sunda, mengembangkan bahasa dan sastra Sunda di Garut dan banyak sekali jasanya dalam mengangkat derajat pribumi. Hal itulah yang membuat pemerintah Garut kembali membangun monumen K. F. Holle yang dibangun di dekat kebun teh Cisaruni, Garut.

\section{Referensi}

A. L. H. Obreen \& L. Van Dam, P. K. F. Holle. De Telegraaf, 1896.

Affandhi, S. K. Album Garoet Tempoe Doeloe. Garut, n.d.

Anonim. “Karel Frederick Holle,” n.d. https://id.wikipedia.org.

Biografisch Woordenboek van Nederland 5. Den Haag, 2002.

Effendie, D. Raden Ajoe Lasminingrat. Garut: CV. Studio Proklamasi, 2011. Ricklefs, M. Sejarah Indonesia Modern 1200-2008. Jakarta: PT. Ilmu

\footnotetext{
${ }^{19}$ Affandhi.
} 
Peran Karel Frederick Holle... | Diky Muhamad Marzuki

Semesta, 2008.

Suhardiman, D. Budaya Garut Dan Pernak Perniknya. Garut: Komunitas Srimanganti, 2007.

Sulasman. Metodologi Penelitian Sejarah. Bandung: Pustaka Setia, 2014. 